The polished irony of this composition finds no parallel in any of the speeches or manifestoes of Sexby. On the other hand the second epistle prefixed, 'To all those Officers and Soldiers of the Army that remember their engagements and dare be honest,' must certainly be by Sexby. Instead of humour there is the fervid passion which marked Sexby's speeches in the council of the army in 1647 , and it is also expressly stated to be written by 'one that was once one amongst you.'

I conclude, therefore, that the pamphlet was the joint work of Sexby and Titus; that the conception and substance of the pamphlet were due to Sexby, and that Titus wrote the dedication to the Protector, supplied the learned quotations and the scientific disquisitions on the nature of tyrants and the right of tyrannicide, and probably corrected the style of the whole. Sexby was, therefore, justified in claiming the authorship of the pamphlet, and he had nothing to gain by the avowal. He did not mention his confederate, either because he regarded his part in the composition as purely subordinate or because he did not wish to expose him to the vengeance of the Protector's government. On the other hand Titus, when he laid claim to be the author of 'Killing No Murder,' stood to gain fame and rewards by it, and did gain both, so that in his case there was a motive for the avowal which was absent in Sexby's case. Fearing no contradiction now that Sexby was dead, he asserted that he was the author of the whole and not merely of certain parts, and represented Sexby as merely an agent charged to print and circulate another man's work. ${ }^{10} \quad$ C. H. Firth.

\title{
The Funeral of Napoleon and his Last Papers.
}

So little is known about the closing scenes of the life of Napoleon except through the prejudiced statements of Montholon and of others of the suite that it may be of interest to publish here some details, drawn from our Colonial Office archives, that bear on these questions. In view of the later assertions of Bertrand and Montholon that the emperor was the victim of liver disease, which was aggravated by the climate of St. Helena and the character of his detention, it is of some importance to note that Montholon's letter of 6 May 1821, written to his countess, then in Europe, contains the following decisive sentences :--

.... L'ouverture de son Corps a eu lieu ce matin : elle a prouvé qu'il étoit mort de la même maladie que son père, un squirre ulcéreux à l'estomac près le pylore; les z de la face de l'estomac étoient ulcérées: il

${ }^{10}$ It will be observed that I have somewhat modified the conclusions stated in the articles on Sexby and Titus in the Dictionary of National Biography, crediting Titus with a share in the pamphlet instead of attributing it solely to Sexby, and defining more exactly what the share of Titus was instead of merely suggesting that he may have bad a hand in it. 
est probable que depuis $4 \dot{\dot{a}} 5$ ans l'ulcère avoit commencé : c'est dans notre malheur une grande consolation pour nous que d'avoir acquis la preuve que sa mort n'est, et n'a pu être, en aucune manière le résultat de sa captivité ni de la privation de tous les soins que l'Europe eût pu offrir à l'espérance.'

The official account of the post mortem examination has been given by Forsyth ; and further details on that topic also appeared in Surgeon Henry's 'Passages of a Military Life,' and in the letters of Major Harrison and Colonel Gorrequer, published in the Cornhill Magazine of February 1901. We therefore proceed to give a paper which has not yet been published-namely, Sir Hudson Lowe's report to Lord Bathurst concerning the funeral.

May 12, 1821.

My Lord,-Pursuant to what I had the honor to inform your Lordship in my Dispatch of the $6^{\text {th }}$ ins ${ }^{\mathrm{t}}$ of my intention to cause the Body of Napoleon Bonaparte to be interred with the Honors due to a General Officer of the Highest Rank, I fixed upon Wednesday the $9^{\text {th }}$ as the day for the Funeral to take place. The accompanying Copy of a General Order given out on the occasion states the form that was observed.

The Corpse, after a funeral service had been performed over it, according to the rites of the Roman Catholic religion, in a small Chapel fitted up for the occasion in Longwood House, was carried by a party of Grenadiers of the Regiment which had been last doing duty over Napoleon Bonaparte's person, to a funeral Car drawn by four of his own carriage horses : $-\&$ the horse he usually rode, fully caparisoned, followed in its rear; his sword, and a mantle which he had worn as General in Chief at the Battle of Marengo, were placed over the Coffin.

The funeral car, followed by the persons who had composed his family as chief mourners, and by the principal officers, civil, naval, and military, on the Island, including the Commissioner of the King of France (charged also with the same duty on the part of the Emperor of Austria), the Naval Commander in Chief, \& myself, passed slowly along the line of Troops, which extended from the entrance of Longwood Grounds, nearly balf-way to the place of interment. The Troops remained with their arms reversed, the several Bands playing a solemn dirge, until the procession had passed them; and when it had reached the extremity of the line, the several Corps filed off from the ground they had taken up in the first instance, and followed in its rear. ${ }^{2}$

1 Colonial Office, St. Helena, no. 32.

2 The general order referred to above shows that the Royal Artillery, with eleven pieces of cannon, were drawn up on the left of the line, the 20th Regiment, a detachment of Royal Marines, the 66th Regiment, the St. Helena Artillery and Regiment and island volunteers successively followed at intervals. The bearers were to be in turn

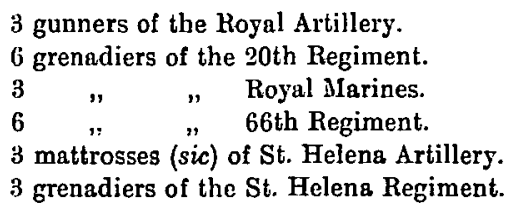

The officers were to wear black crape on their left arms, and the drums were to be muffled. 
On the arrival at that part of the road where the path descended towards the place of burial, the Body was removed from the funeral car, to be borne alternately by the Grenadiers of the several Corps doing duty in this Island, including a party of the Royal Marines, to the spot where the last service was to be performed. The Procession had moved on horseback until it arrived at this Spot, when the whole of the Persons attending dismounted.

The Pall was supported, at their own desire, by the principal persons of Napoleon Bonaparte's Family - the others following the corpse as chief mourners; on the arrival of the Body at the Ground, the usual funeral Ceremony was performed by Signor Vignali, and the Corpse deposited in the Grave. Three rounds of cannon were immediately thereupon fired over it: the Coffin was then covered in, when the Troops and the whole of the Persons who had attended the funeral retired. The Spot, in which the Body is interred, had been designated to me as that in which it had been Napoleon Bonaparte's desire he should be buried if his Remains were left on this Island-close to a small fountain in the middle of a ravine under the shade of two willow trees, in a garden belonging to an Inhabitant of the Island. I have caused the grave to be covered in with masonry and the trees to be inclosed with a rail. I have also placed a guard over it.

I have the honor to be \&c.

Hudson Lowe.

In a later despatch Sir H. Lowe adds a list entitled 'L'Etat de l'Argenterie au 15 Avril 1821,' of which the following were the chief items :-

99 Assiettes ì palmettes ì couteaux, 17 Assiettes à palmettes à soupe, 96 Assiettes de campagne ì couteaux (hors de service), 23 Assiettes à soupe (hors de service), 6 plats ovales, 6 plats d'entrées, 20 plats d'entremets, 2 plats de retiré, 3 boules ovales, 8 boules d'entremets, 50 couteaux, 93 cuillers, 88 fourchettes, 34 cuillers à café, \&c.

This list is far from complete, but the particulars here given will suffice to show that the ostentatious sales of plate, which Montholon and O'Meara represented as necessary to enable the exiles to procure the little comforts denied them, were very far from depleting the stores of plate at Longwood.

Lowe's reports also show that after the funeral his relations with Bertrand and Montholon were cordial enough ; and it seems likely that this was in accordance with one of Napoleon's last injunctions to his followers. At any rate they conferred with the governor on all the details concerning the will and the disposal of the property in a spirit far different from the artificial heat of the earlier years.

But the paper that possesses the chief interest is that sent to Lord Bathurst by Major Gorrequer, who had long been on duty at Longwood. In despatch of 14 May he describes the conversa- 
tions that he had with Bertrand and Montholon on two previous days. I cite here the passages that are of chief interest.

.... Having begged Count Montholon he would show me in the first instance those [papers] which he considered to belong to General Bonaparte himself, be went into his room and brought out a bundle with him. They were principally notes on the Concordat, a rough copy of the letters from the Cape of Good Hope, published as a reply to the book of Mr. Warden, an answer to the 'Manuscrit de Ste. Hélène,' and various loose papers which it would have required an immense time, from the indistinct manner in which many of them were written, simply in pencil, to have deciphered. The heads and subjects of none of them appeared to relate to any object of paramount interest, and upon asking Count Montholon whether nothing more existed he said that I might consider all papers of any kind of consequence as having been already transmitted in one way or another to Europe. He added, Vous en avez même $v u$ de publiese, referring to the ninth book of the 'Memoires.' They had advertised (he said) the publication of the seventh, eighth, and tenth books, but they had not appeared : these had been sent to Mr. O'Meara, but not for publication. He had published what he did without any authority, and they were extremely angry with him for it. He (Count Montholon) would compel Mr. O'Meara to surrender up to him the remainder of the manuscript he had in his possession. General Bonaparte, he said, had been extremely surprised and incensed at the publication of any part of them, as well as of the account of the battle of Waterloo by General Gourgaud, who was desired to deliver up the notes he was possessed of upon that subject previous to his departure from hence; and though he had given up one copy, he had retained, or rather had purloined, the other : that this circumstance had irritated General Bonaparte against General Gourgaud more than anything else in his conduct, and he had never forgiven it.

I asked Count Montholon what had become of the first books of the 'Mémoires.' He said they had been sent home, but he did not mention to whom. He reiterated that every paper which might be considered of any consequence had been sent to Europe a long time since; that General Bonaparte had dictated nothing of any interest since July or August last.

[On the next day, at Sir H. Lowe's request, the papers were arranged, and, as well as the rooms of Longwoud, were submitted to inspection of the officers of the garrison. On 12 May Bertrand and Montholon described some of the works begun but not finished by Napoleon.]

... . a collection of materials for a work in progress on the Archduke Charles's campaigns, which, when he saw that published by the archduke himself, Count Bertrand said, he threw aside, saying, Mais je n'ai écrit que des létises ici; je travaillais en supposant que l'ennemi avait 80,000 ou 100,000 hommes, et je trouve qu'il n'en avoit qu'environ cinquante mille. He had in this manner relinquished several works in contemplation, and others even begun, in consequence of the want of books from which he might have obtained the information which he found necessary as a ground-work to proceed upon-such, for instance, as the strength of armies, their exact positions at particular times, \&c. 
Ceci l'avait beaucoup dégouté de ces ouvrages, parce qu'il n'avoit que sa tête pour travailler-et cela ne lui suffisoit point. ${ }^{3}$ A great many papers were on the Egyptian campaign. Bertrand mentioned that he had particularly urged him to write on the Russian campaign, and that in Saxony, as there was no individual sufficiently acquainted with his plans and objects (during the latter campaign in particular) to write a good account of them, no one but himself being able to explain his dispositions, the multitude of combinations which were put in action, nor the object of many of them. He would not, however, undertake it, but replied they would speak for themselves. The most bulky parcel of papers which Count Bertrand opened was, he said, on the defensive operations of a division by field works and the depth of the formations of troops. The French always formed their line three deep, but, as the rear rank could not fire over the two others in its front, he most approved the English plan of forming two deep only, so long as you could not give effect to the fire of the third rank. This point, Count Bertrand said, had occupied his mind with a particular degree of intenseness. He would get up several times in the middle of the night to write notes upon it, and he frequently sent billets to Count Bertrand on the subject even at night. The whole of that parcel of papers had been prepared during the time he was busied in making his little garden. He there traced out all his plans and field works on the ground, having them all (his followers) about liim, and pointing out to them his ideas. He there described the mode in which he could give effect to the fire of a line drawn up in ranks even as far as ten deep, by placing the ranks on advantageous inclined positions, or drawing them up with the men of lowest stature in front rank and the tallest in the rear. With his ranks eight or ten deep he thought himself perfectly inabordable, and he would hear of no objection to his plans. He would even propose, when the ground did not offer a slope, to make the men dig away a little of the earth, where they were to stand, like steps, which would give sufficient elevation to the rear ranks to fire over those in front; and this he would have done in a minute. When Count Bertrand asked for another minute he said, 'No: in war half a minute is too much to lose; you would have the cavalry upon you and be cut to pieces.' To prove the practicability of such depths of formation in the little garden he would call out, 'Allons, Noverraz, viens ici; tu es le plus grand, plante-toi ld. Vous autres, approchez; and having arranged them according to size on a declivity he went on, 'Et moi, qui suis le plus petit, je serai au dernier rang ;' puis il couchait en joue avec un batton par-dessus nos têtes, exclaiming in triumph, 'Eh bien, ne voyez-vous pas que je tire par-dessus la tête de Noverraz?'

Count Bertrand added that these papers were kept by him mostly

3 This fact shows the need of great caution in accepting Napoleon's 'dictées' on military matters to Montholon. He had to rely on his memory, on the books of bis library (2,700 in number), on files of the Times, and on French newspapers. This was an obviously insufficient basis on which to rear the history of complex campaigns. The British government has been blamed for not supplying Napoleun with the necessary facts. But these facts were buried deep in the archives of Paris, Vienna, Berlin, and St. Petersburg. On these governments lay the chief responsibility in this matter. 
from curiosity. There were, however, a number of interesting things among them, which he intended to put in order, as they would be useful to his sons.

As far as I know, these details have never been fully made known. It is clear from the above account that Bertrand rather than Montholon was the confidant of the ex-emperor in these interesting tactical experiments, which were carried on apparently in the early part of 1820. At that time the British officer on duty reported (1 Feb. 1820), 'I saw General Bonaparte to-day often at his favourite amusement, viz. gardening. He was himself employed placing sods on a bank. In short, his sole amusement at present seems to be building sod walls, making reservoirs to hold water, \&c., and pulling down to-day that which he had reared the day before.'

In view of Bertrand's statement to Gorrequer, cited above, we may doubt whether this piling up of sods had anything to do with gardening, and whether the construction of 'reservoirs' was not really the heaping up of banks to show how a squad of infantry might be arranged so as to double its gun power.

The reference to the campaign of 1813 is also curious. I have always considered the latter half of the Saxon campaign to be the most defective of all the great captain's enterprises; and his refusal to enter into any explanation respecting his plans at that time seems to show that he himself was aware that they were faulty. On none other of his campaigns was he so reticent as on that of 1813.

J. Holuand Rose.

\section{The Convention of Sebtember $\mathbf{1 8 6 4 .}$}

A GOOD deal of matter has been recently published on the September convention. Minghetti's memoir on it, which has long been known to exist, but which apparently he stipulated should not be published till some years after his death, has now appeared. ${ }^{1}$ In addition to his statement of his own position, given here much more fully than in his address $A i$ suoi elettori, published in 1865 , we have a most valuable collection of documents, most of which had not seen the light before. In the Nuora Antologia for 1 March 1899 we have further extracts from Minghetti's correspondence with La Marmora, some of which Minghetti, for good reasons of his own, had omitted. Lastly we have in the second volume of Signor Chiala's life of Dina ${ }^{2}$ the greater part of Pepoli's report on the negotiations (of which only short extracts have previously appeared), extracts from the

+ Forsyth, iii. 210.

1 Minghetti, La Convenzione di Settembre. Bologna: Zanichelli, 1899.

- Giacomo Dina e l'opera sua nelle vicende del Risorgimento Italiano. Turin Roi1x, 1899. 